\title{
Alterations in Behavioral Responses to a Cholinergic Agonist in Post-Pubertal Rats with Neonatal Ventral Hippocampal Lesions: Relationship to Changes in Muscarinic Receptor Levels
}

\author{
François Laplante ${ }^{1,2}$, Osamu Nakagawasai', Lalit K Srivastava' and Rémi Quirion*,1,2 \\ 'Douglas Hospital Research Centre, Department of Psychiatry, McGill University, Montreal, Québec, Canada; ²Department of Pharmacologyl \\ Therapeutics, McGill University, Montréal, Québec, Canada
}

\begin{abstract}
Excitotoxic neonatal ventral hippocampal (NVH) lesion in rats is considered as a putative animal model of schizophrenia as lesioned animals show characteristic post-pubertal emergence of neurochemical and behavioral abnormalities analogous to some of those seen in this disease. Converging evidence points to the involvement of central cholinergic system in this neuropsychiatric disorder, and our previous studies have suggested that cholinergic neurotransmission may be altered in post-pubertal NVH lesioned rats. We investigated here muscarinic receptor reactivity in $\mathrm{NVH}$ lesioned animals by measuring the effects of the muscarinic receptor agonist oxotremorine on physiological responses known to be modulated by these receptors such as body temperature, salivation, tremor, pain, and prepulse inhibition of the acoustic startle (PPI). Quantitative receptor autoradiography revealed that post-pubertal NVH lesioned animals display increased levels of $\left[{ }^{3} \mathrm{H}\right]$ pirenzepine/ $\mathrm{M}_{1}$-like and $\left[{ }^{3} \mathrm{H}\right] \mathrm{AFDX}-384 / \mathrm{M}_{2}$-like receptor binding sites in the striatum, nucleus accumbens, and in subareas of the dorsal hippocampus. Moreover, in response to the systemic administration of oxotremorine $(0.25 \mathrm{mg} / \mathrm{kg})$, post-pubertal $\mathrm{NVH}$ lesioned rats exhibited increases in salivation and tremor, and a greater reduction in body temperature compared to sham control animals. Increases in the hot-plate latency were also observed suggesting enhanced antinociceptive effects of oxotremorine in postpubertal NVH lesioned animals. Finally, oxotremorine $(0.1$ and $0.25 \mathrm{mg} / \mathrm{kg})$ disrupted PPI in post-pubertal sham control rats while the muscarinic receptor antagonist biperiden $(0.5$ and $1.0 \mathrm{mg} / \mathrm{kg})$ normalized this behavior in $\mathrm{NVH}$ lesioned rats. Taken together, these findings reveal that post-pubertal NVH lesioned rats display enhanced muscarinic receptor responsiveness, which may relate to some behavioral abnormalities reported in this animal model.

Neuropsychopharmacology (2005) 30, 1076-1087, advance online publication, 22 December 2004; doi: 10.1038/sj.npp. 1300640
\end{abstract}

Keywords: oxotremorine; prepulse inhibition of the acoustic startle; biperiden; animal model; schizophrenia; receptor autoradiography

\section{INTRODUCTION}

Excitotoxic neonatal ventral hippocampus (NVH) lesions in rats have been proposed as a putative animal model of schizophrenia as these animals display post-pubertal neurochemical and behavioral abnormalities analogous to some symptoms seen in this neuropsychiatric disorders (for reviews see Lipska and Weinberger, 2000; Marcotte et al, 2001). For example, post-pubertal NVH lesioned animals are hyper-reactive to stress and amphetamine, display deficits in prepulse inhibition (PPI) of startle and latent

*Correspondence: Dr R Quirion, Douglas Hospital Research Centre, 6875 LaSalle Blvd, Montréal, PQ, Canada H4H IR3, Tel: + | 5 |4 76| |3| ext.2934, Fax: + | 514888 060,

E-mail: remi.quirion@douglas.mcgill.ca

Received I October 2004; revised 8 November 2004; accepted 10 November 2004

Online publication: I I November 2004 at http://www.acnp.org/citations/ Npp I | | | 04040466/default.pdf inhibition, and impaired social behavior and working memory (Becker et al, 1999; Lipska et al, 1993, 1995, 2002; Sams-Dodd et al, 1997). NVH lesions also induce a number of morphological (Bernstein et al, 1999) and physiological (O'Donnell et al, 2002; Schroeder et al, 1999) changes in the prefrontal cortex (PFC) suggesting the neurodevelopmental reorganization of PFC circuitry.

In post-pubertal NVH lesioned animals, we previously demonstrated greater increases in prefrontal cortical acetylcholine $(\mathrm{ACh})$ release in response to pharmacological stimulation of dopamine (DA) $\mathrm{D}_{1}$-like receptors (Laplante et al, 2004a) and in response to an acute tail pinch stressor (Laplante et al, 2004b). We also reported on the increases in $\mathrm{M}_{1}$-like receptor binding sites in the infralimbic area of the PFC in post-pubertal NVH lesioned rats (Laplante et al, 2004a). These data are suggestive of an altered central cholinergic neurotransmission, which could possibly account, at least in part, for some of the abnormal behaviors described in this animal model. 
Aberrant activities of central cholinergic neurotransmission have been suggested to be involved in major neuropsychiatric disorders including schizophrenia (Sarter, 1994; Sarter and Bruno, 1999) and has been proposed to be implicated in the pathogenesis of depression and stress altered response (Overstreet et al, 1996). Moreover, muscarinic receptor hyperreactivity is suspected to be responsible, at least in part, for the negative symptoms occurring in schizophrenic patients (Tandon et al, 1991, 1993). In accordance with this hypothesis, many studies have reported alterations in cortical and subcortical muscarinic and nicotinic receptor binding sites in schizophrenic brains (for a review see Hyde and Crook, 2001). Moreover, atypical antipsychotics such as clozapine and olanzapine are potent muscarinic receptor antagonists (Bolden et al, 1991; Bymaster et al, 1996).

Besides its well-known roles in attention, learning, and memory (Everitt and Robbins, 1997; Sarter and Bruno, 1997), central cholinergic systems, through the activation of various muscarinic receptor subtypes, regulate numerous physiological processes including body temperature, pain threshold, salivation, and tremor (Dilsaver and Alessi, 1988; Gainetdinov et al, 1999; Gomeza et al, 1999). In the present study, we investigated muscarinic receptors binding sites $\left(M_{1}\right.$ and $M_{2}$-like) in limbic areas of the central nervous system in NVH lesioned rats. Further, using the nonselective muscarinic receptor agonist oxotremorine, we studied the reactivity of muscarinic receptors in physiological functions considered to be dependable measures of the responsiveness of central muscarinic receptors (Dilsaver and Alessi, 1988; Gainetdinov et al, 1999; Gomeza et al, 1999). Finally, as PPI of acoustic startle has also been shown to be modulated by muscarinic receptors (Jones and Shannon, 2000; Wu et al, 1993), we investigated the effects of oxotremorine and the muscarinic receptor antagonist biperiden on this behavior in NVH lesioned rats. Our results suggest that post-pubertal NVH lesioned rats are hyper-sensitive to the stimulation of muscarinic receptors. These findings may be functionally relevant to some behavioral deficits seen in this animal model.

\section{MATERIALS AND METHODS}

\section{Neonatal ventral hippocampal lesions}

Lesions of the ventral hippocampus in pups were performed as previously described (Flores et al, 1996). Pregnant Sprague-Dawley rats at 15 days of gestation were obtained from Charles River Canada (St-Constant, Québec, Canada), housed individually in 12-h light/dark cycle rooms, and fed ad libidum. Animal care and surgery were carried out according to the guidelines approved by the McGill University Animal Care Committee and the Canadian Council for Animal Care.

On postnatal day 7 (PD 7) male pups (14-17g) within each litter (4-9 males/litter) were randomly divided to sham or lesion status. Pups were anesthetized by hypothermia by placing them on ice for 10-20 min and were immobilized on a platform fixed on a stereotaxic frame. An incision in the skin overlaying the skull was made and two $1-\mathrm{mm}$ holes were drilled. A needle connected to an infusion pump through a Hamilton syringe was lowered into each ventral hippocampi at coordinates: $\mathrm{AP}-3.0 \mathrm{~mm} \mathrm{ML} \pm 3.5$ relative to bregma and -5.0 relative to the surface of the skull. Ibotenic acid ( 0.3 and $10 \mu \mathrm{g} / \mu \mathrm{l}$; Sigma, Chemical Co, StLouis, MO) in $0.15 \mathrm{M}$ phosphate buffer saline (PBS) pH 7.4 was infused bilaterally at a flow rate of $0.15 \mu \mathrm{l} / \mathrm{min}$. Sham operated animals received the same volume of PBS. The needle was withdrawn $2 \mathrm{~min}$ after completion of the infusion. Pups were placed under a warming lamp and then returned to their mothers. On PD 21, rats were weaned and grouped 2-3 per cage. Experiments were performed on prepubertal (between PD 32 and 40) and post-pubertal (between PD 56 and 70) animals.

\section{Quantitative Receptor Autoradiography}

Two cohorts of animals from both experimental groups were killed by decapitation: one at PD 35 (prepubertal) and the other at PD 56 (post-pubertal). Brains were removed and frozen in 2-methylbutane at $-40^{\circ} \mathrm{C}$ and stored at $-80^{\circ} \mathrm{C}$. Coronal brain sections $(20 \mu \mathrm{m})$ were cut at $-18^{\circ} \mathrm{C}$ on a cryostat, thaw-mounted on gelatin-coated slides, and stored at $-80^{\circ} \mathrm{C}$ until use.

Muscarinic $\mathrm{M}_{1}$ - and $\mathrm{M}_{2}$-like receptor binding sites were visualized using $\left[{ }^{3} \mathrm{H}\right]$ pirenzepine $(79.3 \mathrm{Ci} / \mathrm{mmol})$ and $\left.{ }^{3} \mathrm{H}\right]$ AFDX-384 (137.0 Ci/mmol) (New England Nuclear, Boston MA), respectively, as described elsewhere (Vaucher et al, 2002). Brain sections were preincubated for $10 \mathrm{~min}$ in Krebs buffer $\left(\mathrm{NaCl} 120 \mathrm{mM}\right.$; $\mathrm{KCl} 4.7 \mathrm{mM} ; \mathrm{CaCl}_{2} 2.5 \mathrm{mM}$; $\mathrm{KH}_{2} \mathrm{PO}_{4} 1.2 \mathrm{mM} ; \mathrm{MgSO}_{4} 1.2 \mathrm{mM}$; glucose $5.6 \mathrm{mM} ; \mathrm{NaHCO}_{3}$ $25 \mathrm{mM}, \mathrm{pH}$ 7.4) at room temperature before a 60 -min incubation into the same buffer containing either $10 \mathrm{nM}$ $\left[{ }^{3} \mathrm{H}\right]$ pirenzepine or $2 \mathrm{nM}\left[{ }^{3} \mathrm{H}\right] \mathrm{AFDX}-384$. Consecutive sections were also incubated in the presence of atropine $(1 \mu \mathrm{M}$; Sigma RBI) to ascertain the specificity of the labelling. Sections were rinsed three times $(4 \mathrm{~min}$ each) in ice-cold Tris- $\mathrm{HCl}$ buffer $(50 \mathrm{mM}, \mathrm{pH}$ 7.4) followed by a rapid dip in ice cold distilled water to removed buffer salts and sections were air dried. Autoradiograms were generated by apposing sections alongside tritium standards to tritium-sensitive films (Amersham, Oakville, ON) for 15 days for $\left[{ }^{3} \mathrm{H}\right]$ pirenzepine binding and 3 weeks for $\left[{ }^{3} \mathrm{H}\right] \mathrm{AFDX}-384$ binding. Films were developed as previously described (Quirion $\mathrm{et} \mathrm{al,}$ 1981 ) and specific labelling quantified ( $\mathrm{fmol} / \mathrm{mg}$ tissues wet weight) using a computer-assisted microdensitometric image analysing system (MCID System, Imaging Research Inc., St Catharines, Ontario, Canada). For both radioligands, quantification was performed bilaterally using four consecutive sections per animal. Sections were anatomically matched between animals by referring to Paxinos and Watson's Brain Atlas (1982).

\section{Functional Measures of Muscarinic Receptor Responsiveness}

Effect of oxotremorine on salivation, tremor, and hypothermia. Rats from each group (sham and $\mathrm{NVH}$ lesion) were injected intraperitoneally with the nonselective muscarinic receptor agonist oxotremorine $(0.25 \mathrm{mg} / \mathrm{kg}$; Sigma RBI, Oakville, ON). Body temperature, salivation, and tremor were assessed before the treatment and at $15 \mathrm{~min}$ intervals for $120 \mathrm{~min}$ after the injection. Body temperature was measured between 12:00 and 14:00 with 
rectal thermometer (FHC Bowdoinham, ME). Salivation and tremor were scored simultaneously in the same animals according to criteria described previously (Gainetdinov et al, 1999). Salivation was scored as $0=$ no salivation; $1=$ moisture on face only; and $2=$ moisture on face and chest. Tremor was scored as $0=$ no tremor; $1=$ intermittent head and body tremor; $2=$ continuous all body tremor.

Antinociceptive effect of oxotremorine. The antinociceptive effect of oxotremorine was investigated using the hot plate test as described by Spreekmeester and Rochford (2000). The hot-plate apparatus was made of $20.3 \times 38.1 \times 20.3 \mathrm{~cm}^{3}$ clear plexiglas chamber mounted on a $0.6-\mathrm{cm}$ thick, $26.7 \times 30.5 \mathrm{~cm}^{2}$ piece of sheet metal. A wooden lid with nine $1 \mathrm{~cm}$ air holes was hinged to the top of the hot plate to prevent animals from escaping. The plate temperature was set to $55^{\circ} \mathrm{C}$ and controlled by immersing the sheet metal into a water bath heated by a Haake E2 Immersion/Open Bath Circulator. Animals were placed on the hot plate and we measured the time required for back paw removal before and $30 \mathrm{~min}$ after the injection of oxotremorine. The maximal time allowed for paw removal was $30 \mathrm{~s}$. The effect of oxotremorine was determined by calculating the percent change between latency 30-min postinjection (L30) and latency prior to injection (L0) according to the formula (L30-L0)/L0 × 100 .

PPI of the acoustic startle response. Tests were conducted using SR-LAB system (SR-LAB, San Diego Instruments, San Diego, CA, USA) that comprised four sound-attenuating chambers each equipped with a cylindrical Plexiglas animal enclosure (length, $16 \mathrm{~cm}$; inner diameter, $8.2 \mathrm{~cm}$ ). Ventilation was provided by a small electric fan that also generated a $70-\mathrm{dB}$ background noise. Tone pulses were presented by a speaker positioned $24 \mathrm{~cm}$ directly above the animal enclosure. A piezoelectric accelerometer affixed to the animal enclosure frame was used to detect and transduce motion resulting from the animal's response. Tone pulse parameters were controlled by a computer using a commercial software package (SR-LAB) and interface assembly that also digitized (0-4095), rectified, and recorded stabilimeter readings.

Measures of both acoustic startle response (ASR) and PPI were obtained in a single session as described by Brake et al (2000) with minor modifications. We investigated the effects of oxotremorine ( 0.1 and $0.25 \mathrm{mg} / \mathrm{kg}$, i.p.) and biperiden hydrochloride ( 0.5 and $1.0 \mathrm{mg} / \mathrm{kg}$, i.p.) (Wako Pure Chemial Industied Ltd, Osaka, Japan), a muscarinic receptor antagonist with preferential affinity for $M_{1}$ receptor (Eltze and Figala, 1988). The tested doses are below the minimal dose $(4 \mathrm{mg} / \mathrm{kg})$ required to produce memory impairment in rats (Roldan et al, 1997). At $20 \mathrm{~min}$ after drug injection, animals were placed in the plexiglas enclosure and allowed to acclimatize to the environment for 5 min before being tested during 37 discrete trials. On the first two trials, the magnitude of the ASR to a $50-\mathrm{ms}$ duration of $120 \mathrm{~dB}$ tone was measured. These first two startle tones were presented in order to habituate the animals to the testing procedure. Therefore, the ASR magnitude of these two trials was omitted from the statistical analysis of the mean ASR amplitude. On the subsequent 35 trials, the startle tone was either presented alone or $100 \mathrm{~ms}$ after presentation of a $30-\mathrm{ms}$ duration prepulse. Prepulse intensity ranged from 6 to $15 \mathrm{~dB}$ above background noise and was varied randomly between trials in $3 \mathrm{~dB}$ steps. Measures were taken at each of the four prepulse intensities on five trials; animals were randomly presented with the startle tone alone during the other 10 trials. The same stimulus condition was never presented on more than two consecutive trials. The interval between each trial was programmed to a variable time schedule with an average duration of $15 \mathrm{~s}$ (range 5-30 s). A measure of startle response amplitude was derived from the mean of 100 digitized data points collected from stimulus onset at a rate of $1 \mathrm{kHz}$. Prepulse effectiveness in suppressing the startle response was expressed as a percentage based on the mean amplitude of responses to the startle tone alone (10 startle tones) relative to those recorded under the four prepulse conditions (5 startle tones/condition): $\% \quad \mathrm{PPI}=($ startle alone-startle in the presence of prepulse)/startle alone) $\times 100 \%$.

Histology. To assess the size and location of the lesion, adult rats were killed by decapitation and brains were removed and frozen in 2-methylbutane at $-40^{\circ} \mathrm{C}$ and then stored at $-80^{\circ} \mathrm{C}$. Coronal sections $(20 \mu \mathrm{m})$ were mounted onto gelatin-coated slides and stained with cresyl violet. Lesion size was examined under light microscopy. As shown in Figure 1, bilateral damage including neuronal loss, atrophy and cavitation of the ventral hippocampus was observed in ibotenic acid-treated rats. Animals exhibiting damage in the dorsal half of the hippocampus, thalamus or cortex were excluded from the study. Sham control animals did not show any obvious damage in hippocampal areas.

Statistical analysis. For quantitative receptor autoradiography, significant differences between experimental groups were determined by $t$-test. Data on salivation and tremor were analyzed by repeated measures two-way analysis of variance (ANOVA) with lesion as independent factor and time after injection as repeated measures. Data on body

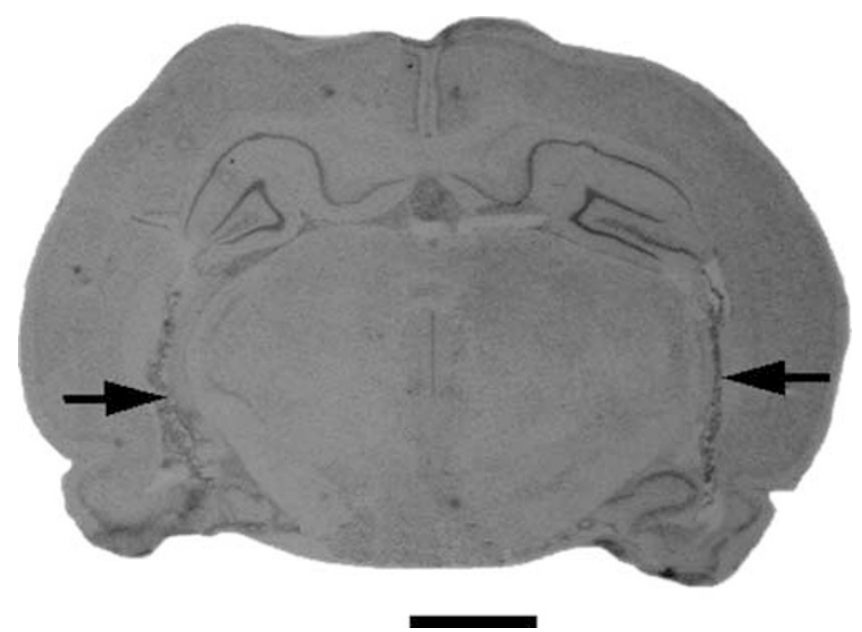

Figure I Histological representation of a coronal section of an adult rat brain stained with cresyl violet demonstrating the structural damage of the ventral hippocampus (arrow) resulting from the neonatal lesion. Scale: $2 \mathrm{~mm}$. 
temperature were analyzed by repeated measures three-way ANOVA with lesion and drug treatment as independent factors and time after injection as repeated measures. The temperature differences were analyzed by two-tailed $T$ test. Hot plate data were analyzed by two-way ANOVA with lesion and drug treatment as independent factors. Post hoc Bonferonni tests were conducted when appropriate. A oneway ANOVA with Dunnett test as post hoc, with sham saline group as reference, was used to assess the magnitude of drug effects on the ASR. The effects of oxotremorine and biperiden on PPI were analyzed separately by three-way repeated-measures ANOVA with lesion and drug as independent factors and prepulse intensity as repeated measures. Post hoc Bonferonni tests were conducted when appropriate.

a

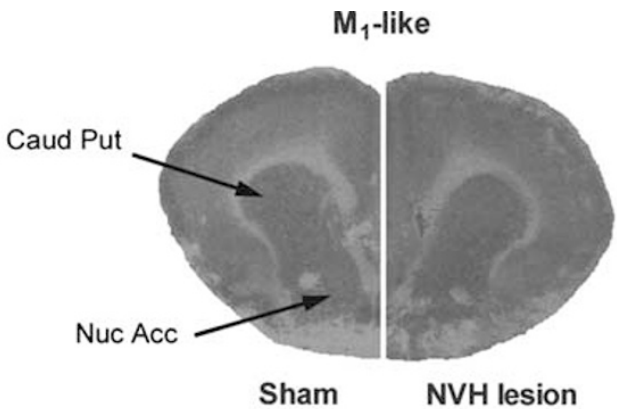

C

$M_{1}$-like

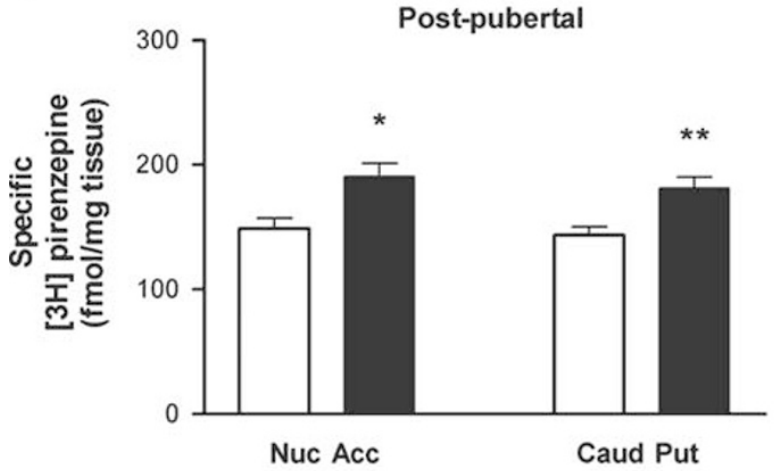

e

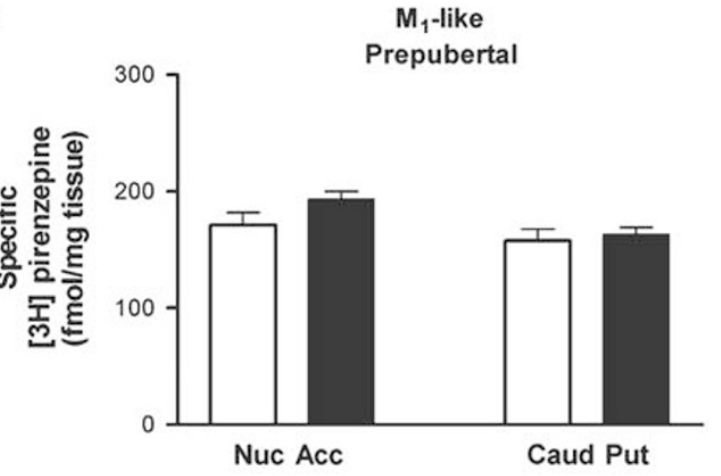

\section{RESULTS}

\section{$M_{1}$ and $M_{2}$-Like Muscarinic Receptor Ligand Binding}

Striatal areas display high levels of specific $\left[{ }^{3} \mathrm{H}\right]$ pirenzepine and $\left[{ }^{3} \mathrm{H}\right]$ AFDX-384 binding (Figure 2a, b). Differences in the amount of specific binding between control and $\mathrm{NVH}$ lesioned rats are not obvious solely on the basis of a visual evaluation of autoradiograms, but quantitative analyses revealed increases in $\mathrm{M}_{1}$-like muscarinic receptor binding in the nucleus accumbens $\left(28 \% ; t_{(8)}=3.10, p=0.015\right)$ and caudate-putamen $\left(26 \% ; t_{(8)}=3.10, p=0.015\right)$ as well as significant increases in $\mathrm{M}_{2}$-like muscarinic receptor binding in the nucleus accumbens $\left(20 \% ; t_{(8)}=2.59, p=0.032\right)$ and caudate-putamen $\left(24 \% ; t_{(8)}=3.60, p=0.007\right)$ in postpubertal NVH lesioned rats (Figure 2c, d). No significant

b
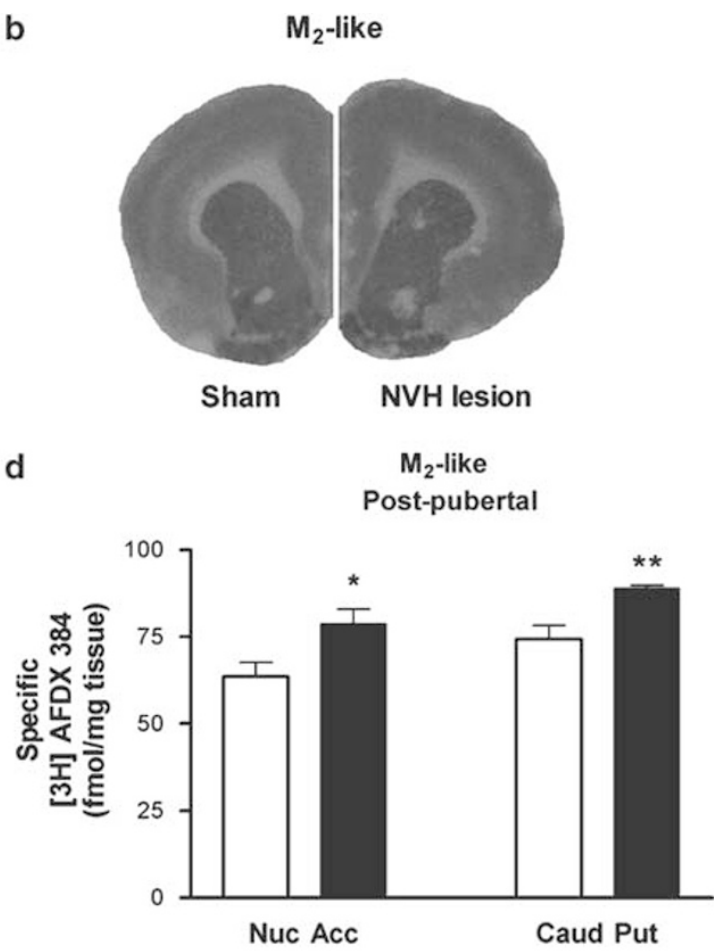

f
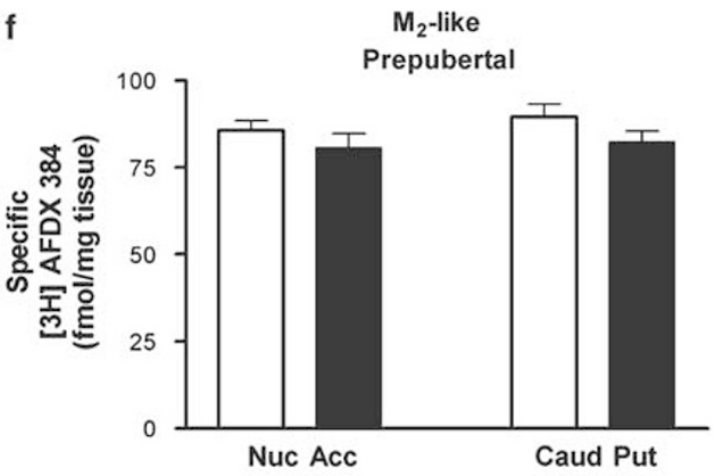

NVH lesion

Figure 2 Quantitative receptor autoradiography of muscarinic binding sites in the striatum. Specific $\left[{ }^{3} H\right]$ pirenzepine $\left(M_{1}\right.$-like) and $\left[{ }^{3} H\right] A F D X 384\left(M_{2}-\right.$ like) represented close to 100\% total binding. (a, b) Representative hemisections of autoradiograms showing that these two receptor classes are expressed in all subareas of the striatum in both sham and NVH lesioned rats. $\left[{ }^{3} \mathrm{H}\right]$ pirenzepine/ $\mathrm{M}_{1}$-like binding sites were quantified in post- (c) and prepubertal (e) animals. Same quantification pattern for specific [ $\left.{ }^{3} \mathrm{H}\right] \mathrm{AFDX} 384 / \mathrm{M}_{2}$-like binding sites (d, f). Data represent mean \pm SEM, $n=5-7$ in each group. $* p<0.05$, *** $<$ 0.0 I. Caud Put, caudate putamen; Nuc Acc, nucleus accumbens. 
a

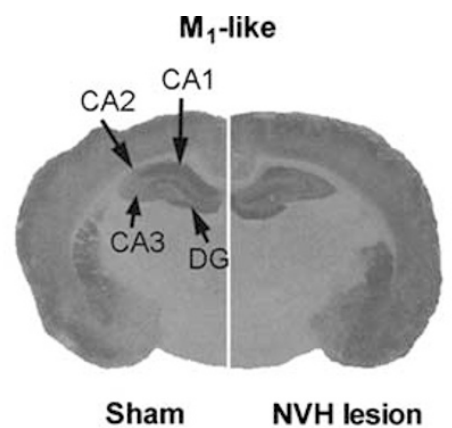

c

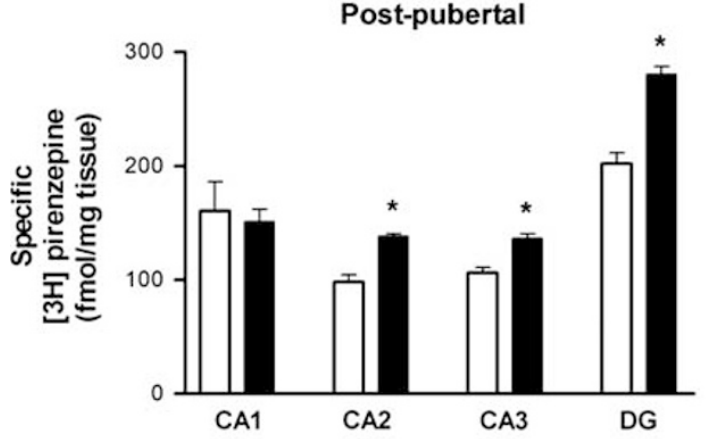

e

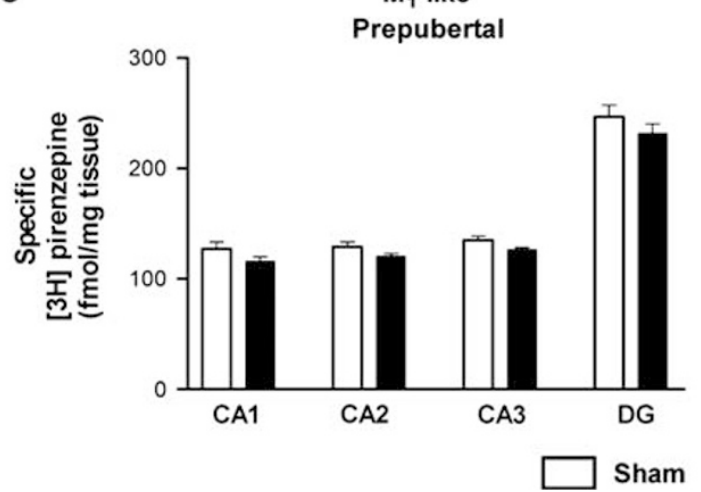

b

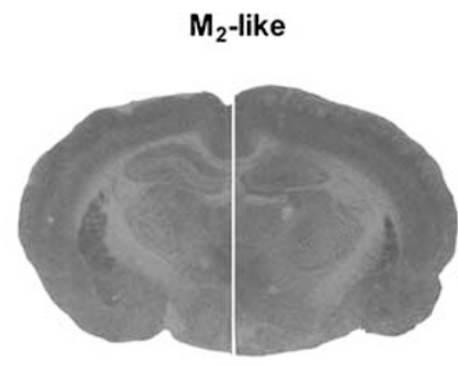

Sham

NVH lesion

d

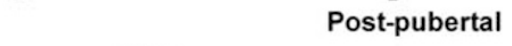

f

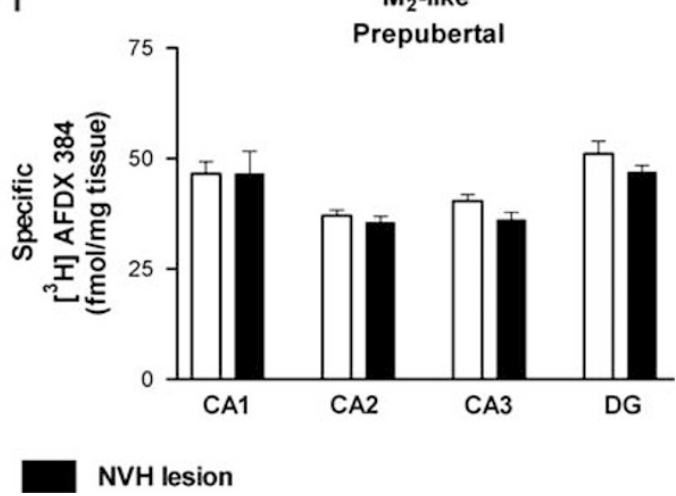

Figure 3 Quantitative receptor autoradiography of muscarinic binding sites in the dorsal hippocampus. Specific $\left[{ }^{3} \mathrm{H}\right]$ pirenzepine $\left(\mathrm{M}_{1}\right.$-like) and $\left[{ }^{3} \mathrm{H}\right] \mathrm{AFDX}$ 384 ( $\mathrm{M}_{2}$-like) represented close to 100\% total binding. $(\mathrm{a}, \mathrm{b})$ Representative hemisections of autoradiograms showing that these two receptor classes are expressed in all subareas of the dorsal hippocampus in sham and $\mathrm{NVH}$ lesioned rats. ${ }^{3} \mathrm{H}$ ]pirenzepine/ $\mathrm{M}_{1}$-like binding sites were quantified in post- (c) and prepubertal (e) animals. Same quantification pattern for specific $\left[{ }^{3} H\right] A F D X 384 / M_{2}$-like binding sites (d, f). Data represent mean $\pm S E M, n=5-7$ in each group. ${ }^{*} p<0.001$. Cal, Ca2, Ca3, subfields of the Ammon's horn of the hippocampus. DG, dentate gyrus.

differences in binding were observed in prepubertal $\mathrm{NVH}$ lesioned rats (Figure 2e, f). Specific $\left[{ }^{3} \mathrm{H}\right]$ pirenzepine and $\left[{ }^{3} \mathrm{H}\right]$ AFDX-384 binding is also seen in the dorsal hippocampus (Figure 3a, b). Significant increases in $\mathrm{M}_{1}$-like receptor binding are observed in the CA2 $\left(41 \% ; t_{(8)}=6.76\right.$, $p=0.0001)$ and CA3 $\left(29 \% ; t_{(8)}=5.82, p=0.0004\right)$ subfields as well as in the dentate gyrus $\left(39 \% ; t_{(8)}=8,56, p<0.0001\right)$ of post-pubertal NVH lesioned rats (Figure 3c). The level of $\mathrm{M}_{2}$-like sites was significantly increased $\left(20 \% ; t_{(13)}=2.54\right.$, $p=0.025$ ) only in the dentate gyrus (Figure $3 \mathrm{~d}$ ) of postpubertal $\mathrm{NVH}$ lesioned rats. As in the striatum, no significant differences in muscarinic receptor binding were observed in the dorsal hippocampus of prepubertal $\mathrm{NVH}$ lesioned rats (Figure 3e, f). Under the experimental conditions used in the present study, it is not possible to ascertain if changes in specific binding relate to alterations in affinity (Kd) and/or maximal binding capacity (Bmax).

\section{Effect of Oxotremorine}

The administration of oxotremorine $(0.25 \mathrm{mg} / \mathrm{kg}$ ip $)$ induced salivation in both post-pubertal sham and $\mathrm{NVH}$ lesioned rats. However, the effect was significantly greater in post-pubertal NVH lesioned rats (Figure 4a). ANOVA revealed a significant main effect of time $\left(\mathrm{F}_{(6,180)}=43.2\right.$; $p<0.0001)$, significant main effect of lesion $\left(\mathrm{F}_{(1,180)}=4.58\right.$; $p=0.041)$ and significant interaction $\left(\mathrm{F}_{(6,180)}=2.40\right.$; $p=0.029)$. The oxotremorine injection also induced tremor in both groups. Again, the tremorogenic effect of oxotremorine was more pronounced in post-pubertal $\mathrm{NVH}$ 


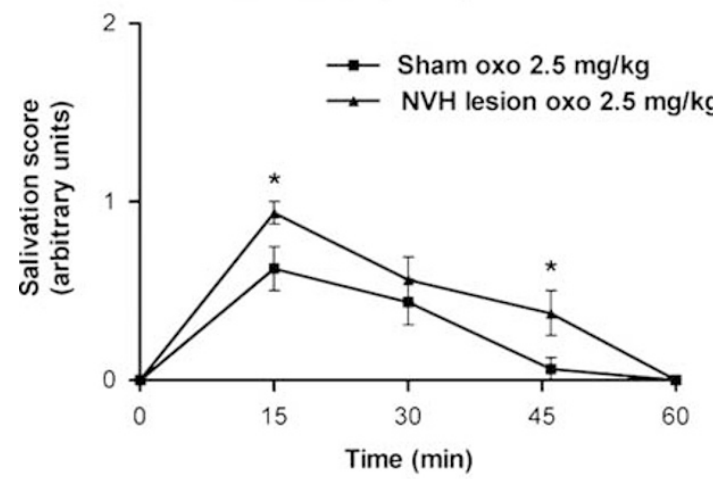

C

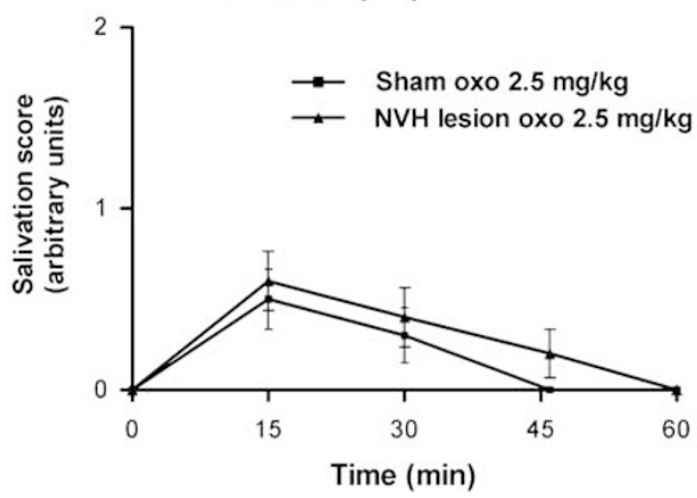

b

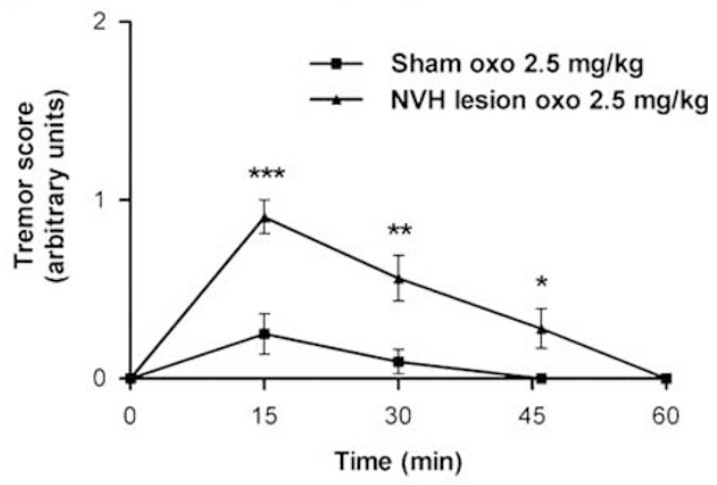

d

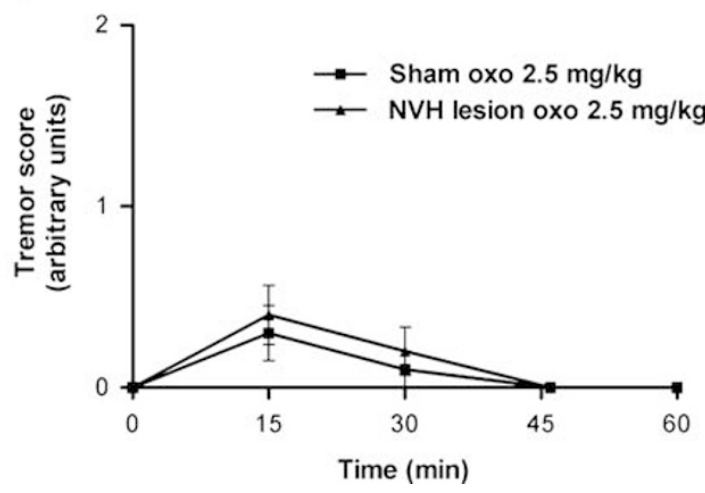

Figure 4 Salivation and tremor in response to the systemic injection of oxotremorine (OXO; $0.25 \mathrm{mg} / \mathrm{kg}$ ) in post-pubertal (a) and (b) and prepubertal (c) and (d) NVH lesioned and sham control rats. Data represent means \pm SEM ( $n=16$ in each group for post-pubertal and $n=10$ for prepubertal). Injection of saline produced no effect on these two responses. Post hoc analysis revealed significant differences between groups. $* p<0.05$; $* * p<0.005$; $* * * p<0.000$ I.

lesioned rats (Figure $4 \mathrm{~b})$. ANOVA revealed a significant main effect of time $\left(\mathrm{F}_{(6,180)}=30.1 ; p<0.0001\right)$, significant main effect of lesion $\left(\mathrm{F}_{(1,180)}=19.1 ; p<0.0001\right)$ and significant interaction $\left(\mathrm{F}_{(6,180)}=11.02 ; p<0.0001\right)$. In prepubertal NVH lesioned animals, the same dose of oxotremorine failed to induce notable differences in salivation and tremor between groups (Figure 4c, d). The effect of oxotremorine on salivation and tremor was worn out 60 min postinjection in all rats.

Muscarinic agonists are known to induce hypothermia. Post-pubertal NVH lesioned rats exhibited a significant lower body temperature compared to sham control following the injection of oxotremorine (Figure 5a). ANOVA revealed a significant main effect of time $\left(\mathrm{F}_{(6,360)}=14.1\right.$; $p<0.0001)$, significant main effect of lesion $\left(\mathrm{F}_{(1,360)}=4.04\right.$; $p=0.049)$, significant main effect of drug treatment $\left(\mathrm{F}_{(1,360)}=90.6 ; p<0.0001\right)$, significant time $\times$ lesion interaction $\left(\mathrm{F}_{(6,360)}=4.52 ; p=0.0002\right)$, significant time $\times$ drug treatment interaction $\left(\mathrm{F}_{(6,360)}=40.5 ; p<0.0001\right)$. By comparing body temperatures pre, as well as 30 and $45 \mathrm{~min}$, postinjection in each animal, we observed that oxotremorine triggered a significantly greater reduction in postpubertal NVH lesioned rats (Figure 5b). Prepubertal NVH lesioned rats did not exhibit significantly lower body temperatures compared to sham control animals following the injection of oxotremorine (Figure 5c). Accordingly, ANOVA revealed a significant main effect of time $\left(F_{(6,192)}=22.6 ; p<0.0001\right)$, significant main effect of drug treatment $\left(\mathrm{F}_{(1,192)}=26.0 ; p<0.0001\right)$, but nonsignificant main effect of lesion $\left(\mathrm{F}_{(1,192)}=0.14 ; p=0.71\right)$ and nonsignificant drug treatment $\times$ lesion interaction $\left(\mathrm{F}_{(1,192)}=0.71 ; p=0.41\right)$.

In the hot plate analgesia task, we observed that $30 \mathrm{~min}$ after administration of oxotremorine $(0.1$ and $0.25 \mathrm{mg} / \mathrm{kg})$, latency to remove the back paw was significantly increased, in a dose-dependent manner, in post-pubertal $\mathrm{NVH}$ lesioned rats (Figure 6a). ANOVA revealed a significant main effect of lesion $\left(\mathrm{F}_{(1,57)}=4.80 ; p=0.033\right)$, a significant main effect of drug treatment $\left(\mathrm{F}_{(2,57)}=3.26 ; p=0.046\right)$ and significant interaction $\left(\mathrm{F}_{(2,57)}=4.09 ; p=0.022\right)$. In prepubertal NVH rats, oxotremorine $(0.25 \mathrm{mg} / \mathrm{kg})$ failed to differentially affect back paw's removal (Figure 6b). ANOVA revealed a nonsignificant main effect of lesion $\left(\mathrm{F}_{(1,35)}=0.25 ; p=0.61\right)$, significant main effect of drug treatment $\left(\mathrm{F}_{(1,35)}=5.32 ; p=0.027\right)$ and nonsignificant interaction $\left(\mathrm{F}_{(1,35)}=1.63 ; p=0.21\right)$.

\section{PPI of the Acoustic Startle}

The effects of oxotremorine and biperiden on the mean ASR magnitude are shown in Figure 7a. ANOVA revealed nonsignificant main effect of lesion $\left(\mathrm{F}_{(1,101)}=0.17\right.$; $p=0.68)$, significant main effect of drug treatment $\left(\mathrm{F}_{(4,101)}=9.82 ; p<0.0001\right)$ and nonsignificant interaction $\left(\mathrm{F}_{(1,101)}=0.30 ; p=0.88\right)$. Post-pubertal NVH lesioned rats exhibited significant reduction in PPI at all prepulse 


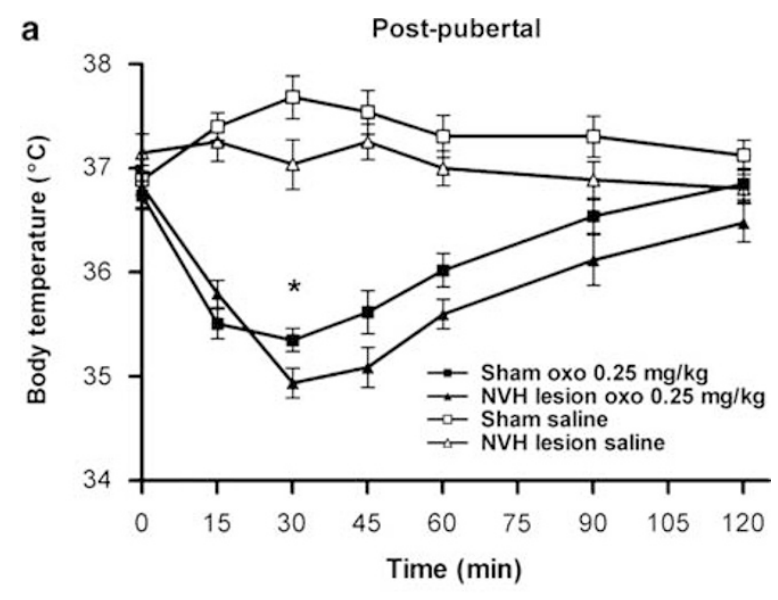

b
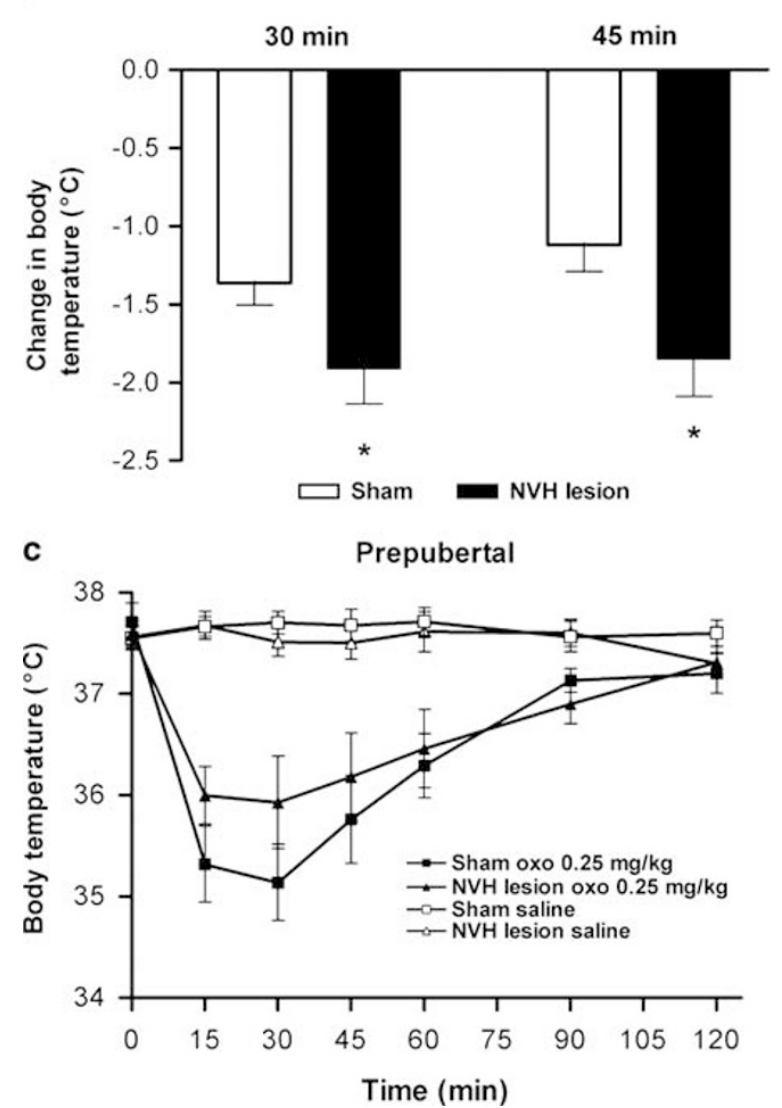

Figure 5 Body temperature (a) measured during a 2-h period following the injection of oxotremorine $(\mathrm{OXO} ; 0.25 \mathrm{mg} / \mathrm{kg}$ ) in post-pubertal $\mathrm{NVH}$ lesioned and sham control rats. (b) Change in body temperature 30 and 45-min postinjection compared to preinjection (time 0). (c) Body temperature measured during a 2 -h period after the injection of oxotremorine (OXO; $0.25 \mathrm{mg} / \mathrm{kg}$ ) in prepubertal $\mathrm{NVH}$ lesioned and sham control rats. Data represent mean \pm SEM ( $n=16$ in each group for postpubertal and $n=8-10$ for prepubertal). Two-tailed $t$-test revealed significant differences between groups. ${ }^{*} p<0.05$.

intensities tested here $(p<0.05)$ (Figure $7 b, c)$ in accordance with previous studies (Le Pen et al, 2003; Lipska et al, 1995). The effects of oxotremorine $(0.1$ and $0.25 \mathrm{mg} / \mathrm{kg})$ on PPI are shown in Figure $7 \mathrm{~b}$. Three-way ANOVA revealed a significant main effect of $\mathrm{NVH}$ lesion $\left(\mathrm{F}_{(1,198)}=22.83\right.$;
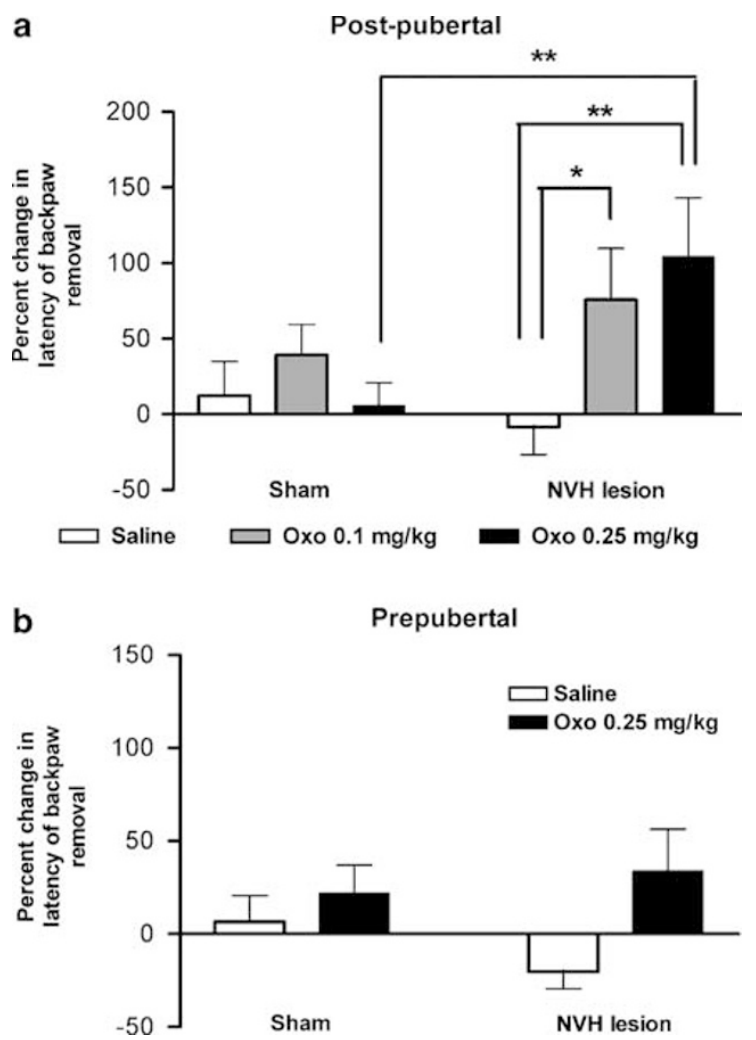

Figure 6 Variation in latency of back paw removal from the hot plate $30 \mathrm{~min}$ following the injection of oxotremorine (OXO; 0,I and $0.25 \mathrm{mg} / \mathrm{kg}$ ) in (a) post and (b) prepubertal NVH lesioned and sham control rats. Data represent mean \pm SEM $(n=10-12$ in each group). Post hoc revealed significant differences of the drug effect between the experimental groups. * $p<0.05$; *** $p<0.01$.

$p<0.0001)$, significant main effect of drug treatment $\left(\mathrm{F}_{(2,198)}=3.26 ; p=0.045\right)$, significant main effect of prepulse intensity $\left(\mathrm{F}_{(3,198)}=44.96 ; p<0.0001\right)$ and significant drug $\times \mathrm{NVH}$ lesion interaction $\left(\mathrm{F}_{(2,198)}=3.31 ; p=0.043\right)$. Post hoc test revealed that oxotremorine dose-dependently disrupted PPI in sham control animals for all prepulse intensities tested. On the other hand, oxotremorine failed to affect PPI in post-pubertal NVH lesioned rats (Figure $7 \mathrm{~b}$ ).

The effects of biperiden $(0.5$ and $1.0 \mathrm{mg} / \mathrm{kg})$ on PPI are summarized in Figure $7 \mathrm{c}$. Three-way ANOVA revealed a significant main effect of $\mathrm{NVH}$ lesion $\left(\mathrm{F}_{(1,165)}=22.8\right.$; $p<0.0001)$, significant main effect of drug treatment $\left(\mathrm{F}_{(2,165)}=5.08 ; p=0.010\right)$, significant main effect of prepulse intensity $\left(\mathrm{F}_{(3,165)}=41.3 ; p<0.0001\right)$, and a significant drug $\times \mathrm{NVH}$ lesion interaction $\left(\mathrm{F}_{(2,165)}=3.85 ; p=0.027\right)$. Post hoc test revealed that biperiden dose-dependently improved PPI deficit in post-pubertal NVH lesioned rats for all prepulse intensities tested while produced no effect in sham control animals (Figure 7c).

\section{DISCUSSION}

In the present study, we have demonstrated that postpubertal NVH lesioned rats exhibit increased levels of both $\mathrm{M}_{1}$ and $\mathrm{M}_{2}$-like muscarinic receptor binding sites in various subareas of the striatum and dorsal hippocampus. Recently, 
a Startle amplitude
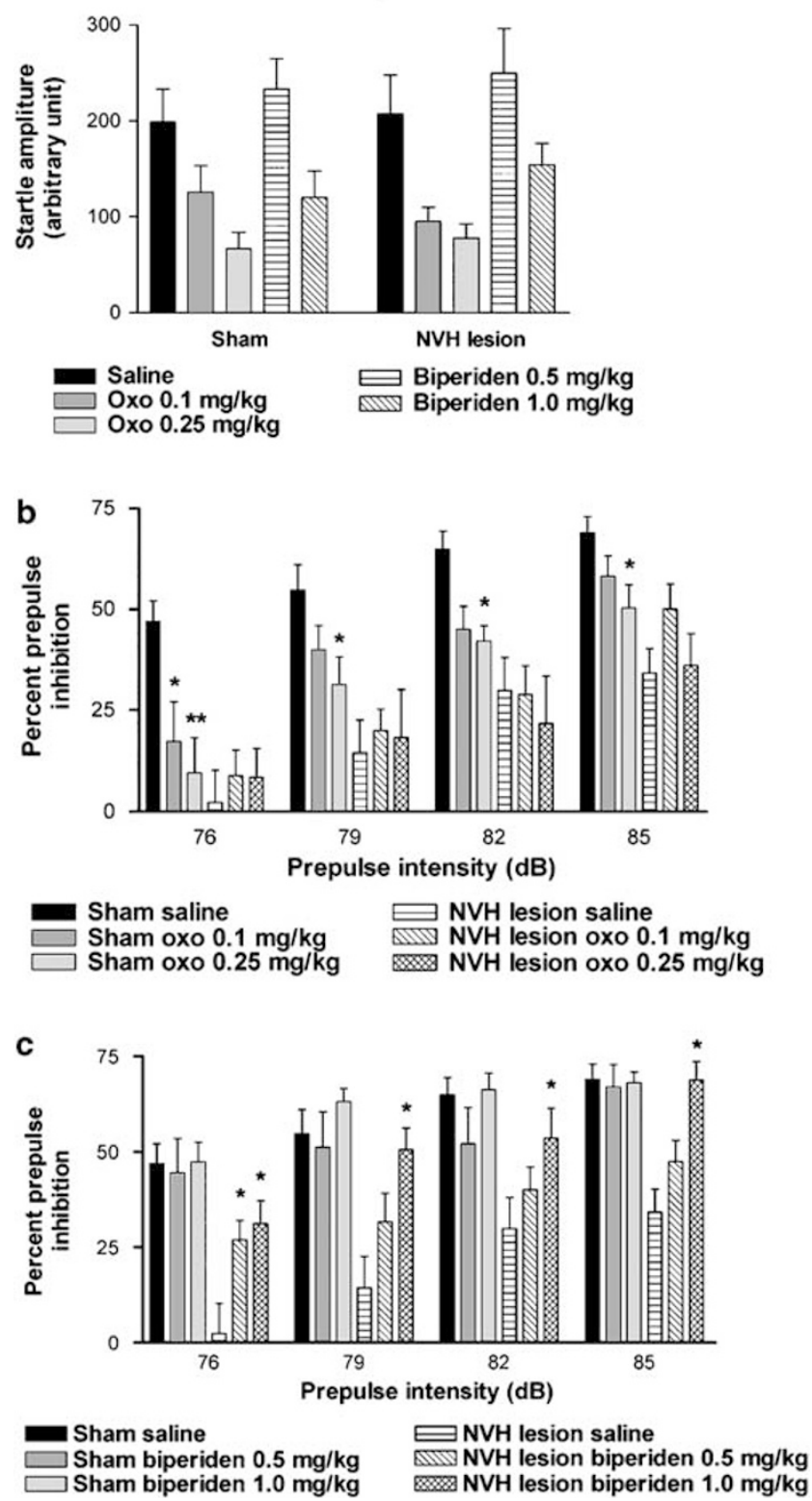

Figure 7 Effects of peripheral administration of oxotremorine (OXO; 0.1 and $0.25 \mathrm{mg} / \mathrm{kg}$ ) and biperiden $(0.5$ and $1.0 \mathrm{mg} / \mathrm{kg}$ ) on acoustic startle response (a). Post hoc analysis revealed no significant drug effects on the mean acoustic startle response magnitude ( $n=7-12$ per group). (b) Peripheral administration of oxotremorine (OXO; 0.1 and $0.25 \mathrm{mg} / \mathrm{kg}$ ) dose-dependently reduced prepulse inhibition (PPI) in control rats as compared with saline injection. $* p<0.05$; ${ }^{*} p<0.01 \quad(n=12$ in each group). (c) Peripheral administration of biperiden $(0.5$ and $1.0 \mathrm{mg} / \mathrm{kg}$ ) increased PPI in post-pubertal NVH lesioned rats. $* p<0.05(n=9-12$ in each group).

we reported increases in $\left[{ }^{3} \mathrm{H}\right]$ pirenzepine/ $\mathrm{M}_{1}$-like muscarinic receptor binding sites in the infralimbic areas of the PFC in post-pubertal NVH lesioned rats (Laplante et al, 2004a). These increases are likely to be functionally relevant as post-pubertal NVH lesioned rats displayed enhanced functional and behavioral responses to systemic administration of the muscarinic agonist, oxotremorine. Indeed, classical responses related to the stimulation of muscarinic receptors such as hypothermia, salivation, and tremor are enhanced in post-pubertal NVH lesioned rats. Oxotremorine also increased latency of back paw removal on the hot plate suggesting an enhanced antinociceptive response. We have previously suggested that prefrontal cortical cholinergic responsiveness is altered in post-pubertal NVH lesioned rats on the basis of greater enhancement in cortical $\mathrm{ACh}$ release in response to the administration of $D_{1}$-like receptor agonist (Laplante et al, 2004a) or tail pinch stressor (Laplante et al, 2004b). The present data extend these earlier results and reveal functional hypersensitivity of muscarinic receptors in post-pubertal NVH lesioned animals.

Interestingly, increased levels of muscarinic receptors and the enhanced effects of oxotremorine in salivation, tremor, hypothermia and anticociception were only seen in postpubertal NVH animals. This is consistent with other neurochemical and behavioral changes that are primarily seen in post-pubertal lesioned animals (Flores et al, 1996; Laplante et al, 2004a; Lipska et al, 1993, 1995; O’Donnell et al, 2002; Schroeder et al, 1999). Thus, these data suggest that NVH lesions result in developmental alterations in central cholinergic neurotransmission.

Oxotremorine decreased PPI in sham animals suggesting that excessive stimulation of muscarinic receptors can impair PPI. However, oxotremorine failed to affect PPI in NVH lesioned rats, which can be explained by the existing lower level of PPI in this animal model. Therefore, further stimulation of muscarinic receptor by oxotremorine did not produce additional deficit. An earlier study reported that the muscarinic receptor agonist pilocarpine was able to impair PPI in normal rats (Stanhope et al, 2001). In contrast, another report failed to demonstrate a disrupting effect of oxotremorine $(0.01-0.3 \mathrm{mg} / \mathrm{kg})$ on PPI in normal rats (Jones and Shannon, 2000). This equivocal result is likely explained by the use of differential testing conditions (background noise: $50 \mathrm{~dB}$, startle pulse: $106 \mathrm{~dB}$, and prepulse intensity: $77 \mathrm{~dB}$ ).

The muscarinic receptor antagonist biperiden significantly improved PPI impairment in post-pubertal NVH lesioned rats. However, biperiden produced no significant effect in sham control animals, in accordance with a previous study (Jones and Shannon, 2000). PPI is regulated by neuronal activity in a set of brain structures that comprise limbic and mesolimbic cortico-striato-pallidopontine circuitry (Klarner et al, 1998). Therefore, it is possible that increased muscarinic receptor binding sites in some limbic and striatal areas and enhanced functional responses are involved in PPI deficits in post-pubertal NVH lesioned rat, and that these deficits can be normalized by decreasing the activity of muscarinic receptors. Interestingly, a previous study has shown that another muscarinic antagonist scopolamine improved kainate-induced PPI disruption in rats (Koch, 1996). These data might be relevant to schizophrenia as well since biperiden was previously shown to improve negative symptoms in schizophrenic patients (Tandon et al, 1991).

Oxotremorine-induced salivation, tremor, hypothermia, and antinociception are considered as dependable measures of the responsiveness of muscarinic receptors in the central nervous system (Dilsaver and Alessi, 1988; Gainetdinov et al, 1999; Gomeza et al, 1999). The effect of muscarinic receptor 
agonist on salivation is though to be predominantly mediated by glandular receptors (Caulfield, 1993). However, salivation is also regulated by CNS muscarinic receptors, which remain to be identified (Sanchez and Meier, 1993). Regarding tremor, it was demonstrated that intrastriatal administration of muscarinic agonists produced tremor (Connor et al, 1966a,b), supporting the involvement of striatal muscarinic receptors in that process. Accordingly, the increased striatal level of muscarinic receptors in postpubertal NVH lesioned rats is consistent with the enhanced oxotremorine-induced tremor. Muscarinic receptors located in hypothalamic thermoregulatory centers contribute predominantly to the regulation of body temperature (Myers, 1980), while muscarinic receptors in the dorsal horn of the spinal cord and the thalamus were shown to reduce pain perception (Harte et al, 2004; Iwamoto and Marion, 1993).

While limbic and striatal areas, may not directly control salivation, body temperature, and pain perception, there is evidence that some of these structures could indirectly participate in these processes. For example, alterations in the PFC are believed to be primarily responsible for the emergence of behavioral and physiological abnormalities observed in the NVH lesioned rats (Lipska et al, 1998; O'Donnell et al, 2002). Anatomical evidence from rats and monkeys demonstrated that some PFC neurons project to several brain areas notably the striatum, thalamus, hypothalamus, and brainstem, notably to the nucleus of solitary tract (Chiba et al, 2001; Van Eden and Buijs, 2000; Vertes, 2004). Accordingly, the PFC, particularly its infralimbic area, can regulate visceral/autonomic functions including cardiovascular response, respiration, gastrointestinal activity, and thermoregulation (Neafsey, 1990). Infusions of the muscarinic receptor agonist carbachol in the PFC were able to enhance cardioacceleratory responses to aversive stimuli (Berntson et al, 1996; Hart et al, 1999), demonstrating that cholinergic neurotransmission in this cortical area may be involved in the regulation of some autonomic functions in reaction to stress and anxiety. Interestingly, cardiovascular stress responses in rats were shown to be reduced by atypical antipsychotic drugs (eg clozapine), which display high affinity for muscarinic receptors but not by the typical antipsychotic, haloperidol (Van Den Buuse, 2003). In addition, PFC neurons project to the spinal cord (Van Eden and Buijs, 2000) where they can influence nociception. For example, the stimulation of the PFC was shown to reduce behavioral response to noxious stimuli (Hardy and Haigler, 1985; Hardy, 1985). Since infralimbic $P F C M_{1}$ receptors can mediate anxiety responses (Wall et al, 2001), increased $\mathrm{M}_{1}$ binding in this cortical area in post-pubertal NVH lesioned rats (Laplante et al, 2004a) may result in increased ACh-mediated signaling in the PFC leading to activated visceral/autonomic functions in these animals.

While data from an animal model may not be directly extrapolated to human schizophrenia, a disorder of predominantly psychological symptoms, it is of interest that in accordance with dysregulation in PFC activities reported in schizophrenia (Callicott, 2003; Weinberger et al, 2001; Yang et al, 1999), a wide variety of somatic manifestations have been also reported, particularly in the older literature. Some of the physical symptoms of schizophrenia described by Kraepelin (1919) included diminished sensitivity to pain, increased secretion of saliva, tremor, seizures, and lower body temperature (Kraepelin, 1919). In addition, recent studies have reported that schizophrenic patients often develop thermoregulatory disturbances (Shiloh et al, 2001) and have increased pain threshold (Dworkin, 1994; Lautenbacher and Krieg, 1994).

In the present study, $\mathrm{M}_{1^{-}}$and $\mathrm{M}_{2}$-like muscarinic receptors binding was increased in the striatal and hippocampal regions of post-pubertal NVH lesioned rats. These results are in contrast with most post mortem and SPECT studies reporting decreased levels of muscarinic receptors in the $\mathrm{PFC}$, striatum and hippocampus of schizophrenic patients (Crook et al, 1999, 2000, 2001; Dean et al, 1996; Raedler et al, 2003). The decreased levels of muscarinic receptors in schizophrenia may reflect a downregulation in response to increased ACh efflux associated with increased dopaminergic neurotransmission (Crook et $a l, 2001)$ or in response to long-term neuroleptic treatments. A similar phenomenon may not occur in drug-naïve NVH lesioned rats. Moreover, we have shown that basal levels of PFC ACh release are not altered in postpubertal NVH lesioned rats compared to sham littermates (Laplante et al, 2004a, b). However, NVH lesions affect the development of neural circuitry implicated in stress response (Lipska et al, 1993) resulting into enhanced DA neurotransmission (Flores et al, 1996; Lipska et al, 1993; O'Donnell et al, 2002). The increased responsiveness of cholinergic neurotransmissiom may reflect a compensatory mechanism to sensitized DA activity. Accordingly, increased cholinergic neurotransmission was proposed as a counter-balance to increased mesolimbic DA activity to dampen positive symptoms of schizophrenia (Tandon, 1999).

As oxotremorine is a nonselective muscarinic receptor agonist, this study was unable to determine which receptor subtype(s) is involved in the hyper-responsiveness to this drug in our model. Recently, however, the use of muscarinic receptor knockout mice suggested the involvement of various subtypes in multiple physiological processes (Wess, 2004). Accordingly, oxotremorine-induced tremor response was shown to be mediated by $\mathrm{M}_{2}$ receptors (Bymaster et al, 2003; Gomeza et al, 1999), with the $\mathrm{M}_{1}$ receptors contribution to pilocarpine-induced seizure (Bymaster et al, 2003; Hamilton et al, 1997). Muscarinic agonist-induced salivation was shown to be mostly mediated by $M_{3}$ receptors (Matsui et al, 2000) with more minor role for the $\mathrm{M}_{1}, \mathrm{M}_{4}$, and $\mathrm{M}_{5}$ subtypes (Bymaster et al, 2003; Takeuchi et al, 2002). $M_{2}$ receptors were shown to play a predominant role in the hypothermic effect of oxotremorine (Bymaster et al, 2003; Gomeza et al, 1999) with an additional contribution of the $\mathrm{M}_{3}$ subtype (Bymaster et al, 2003). Finally, the analgesic effect of oxotremorine was reported to be predominantly modulated by $\mathrm{M}_{2}$ receptors with a small contribution of the $\mathrm{M}_{4}$ subtype (Gomeza et al, 1999; Duttaroy et al, 2002). Further studies will be required to establish which muscarinic receptor subtype(s) is mostly involved in oxotremorine-hyper-responsiveness in NVH lesioned rats.

Muscarinic receptors are known to be involved in other behaviors such as attention, and working and spatial memories (Everitt and Robbins, 1997; Sarter and Bruno, 1997; Quirion et al, 1995; Rowe et al, 2003), which were reported to be impaired in post-pubertal NVH lesioned rats 
(Grecksch et al, 1999; Le Pen et al, 2000; Lipska et al, 2002). The present data showing increased levels of both $\mathrm{M}_{1}$ - and $\mathrm{M}_{2}$-like muscarinic receptor binding sites and heightened responsiveness to oxotremorine further suggest a role for muscarinic cholinergic neurotransmission in some behavioral impairment reported in this animal model, and add support to the functional relevance of cholinergic neurotransmission in schizophrenia.

\section{ACKNOWLEDGEMENTS}

This work was supported by grants from the Canadian Institutes of Health Research (CIHR). L Srivastava is a 'Chercheur National' of the 'Fonds de la Recherche en Santé du Québec'. F Laplante holds a studentship from CIHR.

\section{REFERENCES}

Becker A, Grecksch G, Bernstein HG, Hollt V, Bogerts B (1999). Social behaviour in rats lesioned with ibotenic acid in the hippocampus: quantitative and qualitative analysis. Psychopharmacology (Berl) 144: 333-338.

Bernstein HG, Grecksch G, Becker A, Hollt V, Bogerts B (1999). Cellular changes in rat brain areas associated with neonatal hippocampal damage. Neuroreport 10: 2307-2311.

Berntson GG, Hart S, Ruland S, Sarter M (1996). A central cholinergic link in the cardiovascular effects of the benzodiazepine receptor partial inverse agonist FG 7142. Behav Brain Res 74: 91-103.

Bolden C, Cusack B, Richelson E (1991). Clozapine is a potent and selective muscarinic antagonist at the five cloned human muscarinic acetylcholine receptors expressed in CHO-K1 cells. Eur J Pharmacol 192: 205-206.

Brake WG, Flores G, Francis D, Meaney MJ, Srivastava LK, Gratton A (2000). Enhanced nucleus accumbens dopamine and plasma corticosterone stress responses in adult rats with neonatal excitotoxic lesions to the medial prefrontal cortex. Neuroscience 96: 687-695.

Bymaster FP, Calligaro DO, Falcone JF, Marsh RD, Moore NA, Tye NC et al (1996). Radioreceptor binding profile of the atypical antipsychotic olanzapine. Neuropsychopharmacology 14: 87-96.

Bymaster FP, Carter PA, Yamada M, Gomeza J, Wess J, Hamilton SE et al (2003). Role of specific muscarinic receptor subtypes in cholinergic parasympathomimetic responses, in vivo phosphoinositide hydrolysis, and pilocarpine-induced seizure activity. Eur J Neurosci 17: 1403-1410.

Callicott JH (2003). An expanded role for functional neuroimaging in schizophrenia. Curr Opin Neurobiol 13: 256-260.

Caulfield MP (1993). Muscarinic receptors - characterization, coupling and function. Pharmacol Ther 58: 319-379.

Chiba T, Kayahara T, Nakano K (2001). Efferent projections of infralimbic and prelimbic areas of the medial prefrontal cortex in the Japanese monkey, Macaca fuscata. Brain Res 888: 83-101.

Connor JD, Rossi GV, Baker WW (1966a). Analysis of the tremor induced by injection of cholinergic agents into the caudate nucleus. Int J Neuropharmacol 5: 207-216.

Connor JD, Rossi GV, Baker WW (1966b). Characteristics of tremor in cats following injections of carbachol into the caudate nucleus. Exp Neurol 14: 371-382.

Crook JM, Dean B, Pavey G, Copolov D (1999). The binding of $\left[{ }^{3} \mathrm{H}\right] \mathrm{AF}-\mathrm{DX} 384$ is reduced in the caudate-putamen of subjects with schizophrenia. Life Sci 64: 1761-1771.

Crook JM, Tomaskovic-Crook E, Copolov DL, Dean B (2000). Decreased muscarinic receptor binding in subjects with schizophrenia: a study of the human hippocampal formation. Biol Psychiatry 48: 381-388.
Crook JM, Tomaskovic-Crook E, Copolov DL, Dean B (2001). Low muscarinic receptor binding in prefrontal cortex from subjects with schizophrenia: a study of Brodmann's areas $8,9,10$, and 46 and the effects of neuroleptic drug treatment. Am J Psychiatry 158: 918-925.

Dean B, Crook JM, Opeskin K, Hill C, Keks N, Copolov DL (1996). The density of muscarinic M1 receptors is decreased in the caudate-putamen of subjects with schizophrenia. Mol Psychiatry 1: $54-58$.

Dilsaver SC, Alessi NE (1988). Temperature as a dependent variable in the study of cholinergic mechanisms. Prog Neuropsychopharmacol Biol Psychiatry 12: 1-32.

Duttaroy A, Gomeza J, Gan JW, Siddiqui N, Basile AS, Harman WD et al (2002). Evaluation of muscarinic agonist-induced analgesia in muscarinic acetylcholine receptor knockout mice. $\mathrm{Mol}$ Pharmacol 62: 1084-1093.

Dworkin RH (1994). Pain insensitivity in schizophrenia: a neglected phenomenon and some implications. Schizophr Bull 20: $235-248$

Eltze M, Figala V (1988). Affinity and selectivity of biperiden enantiomers for muscarinic receptor subtypes. Eur J Pharmacol 158: $11-19$.

Everitt BJ, Robbins TW (1997). Central cholinergic systems and cognition. Annu Rev Psychol 48: 649-684.

Flores G, Barbeau D, Quirion R, Srivastava LK (1996). Decreased binding of dopamine D3 receptors in limbic subregions after neonatal bilateral lesion of rat hippocampus. J Neurosci 16: 2020-2026.

Gainetdinov RR, Bohn LM, Walker JK, Laporte SA, Macrae AD, Caron MG et al (1999). Muscarinic supersensitivity and impaired receptor desensitization in $\mathrm{G}$ protein-coupled receptor kinase 5-deficient mice. Neuron 24: 1029-1036.

Gomeza J, Shannon H, Kostenis E, Felder C, Zhang L, Brodkin J et al (1999). Pronounced pharmacologic deficits in M2 muscarinic acetylcholine receptor knockout mice. Proc Natl Acad Sci USA 96: 1692-1697.

Grecksch G, Bernstein HG, Becker A, Hollt V, Bogerts B (1999). Disruption of latent inhibition in rats with postnatal hippocampal lesions. Neuropsychopharmacology 20: 525-532.

Hamilton SE, Loose MD, Qi M, Levey AI, Hille B, McKnight GS et al (1997). Disruption of the $\mathrm{m} 1$ receptor gene ablates muscarinic receptor-dependent $M$ current regulation and seizure activity in mice. Proc Natl Acad Sci USA 94: 13311-13316.

Hardy SG (1985). Analgesia elicited by prefrontal stimulation. Brain Res 339: 281-284.

Hardy SG, Haigler HJ (1985). Prefrontal influences upon the midbrain: a possible route for pain modulation. Brain Res 339: 285-293.

Hart S, Sarter M, Berntson GG (1999). Cholinergic inputs to the rat medial prefrontal cortex mediate potentiation of the cardiovascular defensive response by the anxiogenic benzodiazephine receptor partial inverse agonist FG 7142. Neuroscience 94: 1029-1038.

Harte SE, Hoot MR, Borszcz GS (2004). Involvement of the intralaminar parafascicular nucleus in muscarinic-induced antinociception in rats. Brain Res 1019: 152-161.

Hyde TM, Crook JM (2001). Cholinergic systems and schizophrenia: primary pathology or epiphenomena? J Chem Neuroanat 22: 53-63.

Iwamoto ET, Marion L (1993). Characterization of the antinociception produced by intrathecally administered muscarinic agonists in rats. J Pharmacol Exp Ther 266: 329-338.

Jones CK, Shannon HE (2000). Muscarinic cholinergic modulation of prepulse inhibition of the acoustic startle reflex. J Pharmacol Exp Ther 294: 1017-1023.

Klarner A, Koch M, Schnitzler HU (1998). Induction of Fos-protein in the forebrain and disruption of sensorimotor gating following 
$N$-methyl-D-aspartate infusion into the ventral hippocampus of the rat. Neuroscience 84: 443-452.

Koch M (1996). The septohippocampal system is involved in prepulse inhibition of the acoustic startle response in rats. Behav Neurosci 110: 468-477.

Kraepelin E (1919). Dementia Praecox and Paraphrenia. E\&S Livingstone: Edinburgh.

Laplante F, Srivastava LK, Quirion R (2004a). Alterations in dopaminergic modulation of prefrontal cortical acetylcholine release in post-pubertal rats with neonatal ventral hippocampal lesions. J Neurochem 89: 314-323.

Laplante F, Stevenson CW, Gratton A, Srivastava LK, Quirion R (2004b). Effects of neonatal ventral hippocampal lesion in rats on stress-induced acetylcholine release in the prefrontal cortex. J Neurochem 91: 1473-1482.

Lautenbacher S, Krieg JC (1994). Pain perception in psychiatric disorders: a review of the literature. J Psychiatr Res 28: 109-122.

Le Pen G, Grottick AJ, Higgins GA, Martin JR, Jenck F, Moreau JL (2000). Spatial and associative learning deficits induced by neonatal excitotoxic hippocampal damage in rats: further evaluation of an animal model of schizophrenia. Behav Pharmacol 11: 257-268.

Le Pen G, Kew J, Alberati D, Borroni E, Heitz MP, Moreau JL (2003). Prepulse inhibition deficits of the startle reflex in neonatal ventral hippocampal-lesioned rats: reversal by glycine and a glycine transporter inhibitor. Biol Psychiatry 54: $1162-1170$.

Lipska BK, Al Amin HA, Weinberger DR (1998). Excitotoxic lesions of the rat medial prefrontal cortex. Effects on abnormal behaviors associated with neonatal hippocampal damage. Neuropsychopharmacology 19: 451-464.

Lipska BK, Aultman JM, Verma A, Weinberger DR, Moghaddam B (2002). Neonatal damage of the ventral hippocampus impairs working memory in the rat. Neuropsychopharmacology 27: 47-54.

Lipska BK, Jaskiw GE, Weinberger DR (1993). Post-pubertal emergence of hyperresponsiveness to stress and to amphetamine after neonatal excitotoxic hippocampal damage: a potential animal model of schizophrenia. Neuropsychopharmacology 9: 67-75.

Lipska BK, Swerdlow NR, Geyer MA, Jaskiw GE, Braff DL, Weinberger DR (1995). Neonatal excitotoxic hippocampal damage in rats causes post-pubertal changes in prepulse inhibition of startle and its disruption by apomorphine. Psychopharmacology (Berl) 122: 35-43.

Lipska BK, Weinberger DR (2000). To model a psychiatric disorder in animals: schizophrenia as a reality test. Neuropsychopharmacology 23: 223-239.

Marcotte ER, Pearson DM, Srivastava LK (2001). Animal models of schizophrenia: a critical review. J Psychiatry Neurosci 26: 395-410.

Matsui M, Motomura D, Karasawa H, Fujikawa T, Jiang J, Komiya $\mathrm{Y}$ et al (2000). Multiple functional defects in peripheral autonomic organs in mice lacking muscarinic acetylcholine receptor gene for the M3 subtype. Proc Natl Acad Sci USA 97: 9579-9584.

Myers RD (1980). Handbook of the Hypothalamus. Marcel Dekker: New York. pp 83-210.

Neafsey EJ (1990). Prefrontal cortical control of the autonomic nervous system: anatomical and physiological observations. Prog Brain Res 85: 147-165.

O'Donnell P, Lewis BL, Weinberger DR, Lipska BK (2002). Neonatal hippocampal damage alters electrophysiological properties of prefrontal cortical neurons in adult rats. Cereb Cortex 12: $975-982$.

Overstreet DH, Miller CS, Janowsky DS, Russell RW (1996). Potential animal model of multiple chemical sensitivity with cholinergic supersensitivity. Toxicology 111: 119-134.
Paxinos G, Watson C (1982). The Rat Brain in Stereotaxic Coordinates. Academic Press: New York.

Quirion R, Hammer Jr RP, Herkenham M, Pert CB (1981). Phencyclidine (angel dust)/sigma 'opiate' receptor: visualization by tritium-sensitive film. Proc Natl Acad Sci USA 78: 5881-5885.

Quirion R, Wilson A, Rowe W, Aubert I, Richard J, Doods H et al (1995). Facilitation of acetylcholine release and cognitive performance by an $\mathrm{M}(2)$-muscarinic receptor antagonist in aged memory-impaired. J Neurosci 15: 1455-1462.

Raedler TJ, Knable MB, Jones DW, Urbina RA, Gorey JG, Lee KS et al (2003). In vivo determination of muscarinic acetylcholine receptor availability in schizophrenia. Am J Psychiatry 160: 118127.

Roldan G, Bolanos-Badillo E, Gonzalez-Sanchez H, Quirarte GL, Prado-Alcala RA (1997). Selective M1 muscarinic receptor antagonists disrupt memory consolidation of inhibitory avoidance in rats. Neurosci Lett 230: 93-96.

Rowe WB, O’Donnell JP, Pearson D, Rose GM, Meaney MJ, Quirion R (2003). Long-term effects of BIBN-99, a selective muscarinic M2 receptor antagonist, on improving spatial memory performance in aged cognitively impaired rats. Behav Brain Res 145: 171-178.

Sams-Dodd F, Lipska BK, Weinberger DR (1997). Neonatal lesions of the rat ventral hippocampus result in hyperlocomotion and deficits in social behaviour in adulthood. Psychopharmacology (Berl) 132: 303-310.

Sanchez C, Meier E (1993). Central and peripheral mediation of hypothermia, tremor and salivation induced by muscarinic agonists in mice. Pharmacol Toxicol 72: 262-267.

Sarter M (1994). Neuronal mechanisms of the attentional dysfunctions in senile dementia and schizophrenia: two sides of the same coin? Psychopharmacology (Berl) 114: 539-550.

Sarter M, Bruno JP (1997). Cognitive functions of cortical acetylcholine: toward a unifying hypothesis. Brain Res Brain Res Rev 23: 28-46.

Sarter M, Bruno JP (1999). Abnormal regulation of corticopetal cholinergic neurons and impaired information processing in neuropsychiatric disorders. Trends Neurosci 22: 67-74.

Schroeder H, Grecksch G, Becker A, Bogerts B, Hoellt V (1999). Alterations of the dopaminergic and glutamatergic neurotransmission in adult rats with postnatal ibotenic acid hippocampal lesion. Psychopharmacology (Berl) 145: 61-66.

Shiloh R, Weizman A, Epstein Y, Rosenberg SL, Valevski A, Dorfman-Etrog P et al (2001). Abnormal thermoregulation in drug-free male schizophrenia patients. Eur Neuropsychopharmacol 11: 285-288.

Spreekmeester E, Rochford J (2000). Selective mu and delta, but not kappa, opiate receptor antagonists inhibit the habituation of novelty-induced hypoalgesia in the rat. Psychopharmacology (Berl) 148: 99-105.

Stanhope KJ, Mirza NR, Bickerdike MJ, Bright JL, Harrington NR, Hesselink MB et al (2001). The muscarinic receptor agonist xanomeline has an antipsychotic-like profile in the rat. J Pharmacol Exp Ther 299: 782-792.

Takeuchi J, Fulton J, Jia ZP, Abramov-Newerly W, Jamot L, Sud M et al (2002). Increased drinking in mutant mice with truncated M5 muscarinic receptor genes. Pharmacol Biochem Behav 72: 117-123.

Tandon R (1999). Cholinergic aspects of schizophrenia. $\mathrm{Br}$ Psychiatry 174(Suppl 37): 7-11.

Tandon R, Greden JF, Haskett RF (1993). Cholinergic hyperactivity and negative symptoms: behavioral effects of physostigmine in normal controls. Schizophr Res 9: 19-23.

Tandon R, Shipley JE, Greden JF, Mann NA, Eisner WH, Goodson JA (1991). Muscarinic cholinergic hyperactivity in schizophrenia. Relationship to positive and negative symptoms. Schizophr Res 4: 23-30. 
Van Den Buuse M (2003). Acute effects of antipsychotic drugs on cardiovascular responses to stress. Eur J Pharmacol 464: 55-62.

Van Eden CG, Buijs RM (2000). Functional neuroanatomy of the prefrontal cortex: autonomic interactions. Prog Brain Res 126: 49-62.

Vaucher E, Fluit P, Chishti MA, Westaway D, Mount HT, Kar S (2002). Object recognition memory and cholinergic parameters in mice expressing human presenilin 1 transgenes. Exp Neurol 175: 398-406.

Vertes RP (2004). Differential projections of the infralimbic and prelimbic cortex in the rat. Synapse 51: 32-58.

Wall PM, Flinn J, Messier C (2001). Infralimbic muscarinic M1 receptors modulate anxiety-like behaviour and spontaneous working memory in mice. Psychopharmacology (Berl) 155: 58-68.
Weinberger DR, Egan MF, Bertolino A, Callicott JH, Mattay VS, Lipska BK et al (2001). Prefrontal neurons and the genetics of schizophrenia. Biol Psychiatry 50: 825-844.

Wess J (2004). Muscarinic acetylcholine receptor knockout mice: novel phenotypes and clinical implications. Annu Rev Pharmacol Toxicol 44: 423-450.

Wu MF, Jenden DJ, Fairchild MD, Siegel JM (1993). Cholinergic mechanisms in startle and prepulse inhibition: effects of the false cholinergic precursor $\mathrm{N}$-aminodeanol. Behav Neurosci 107: 306-316.

Yang CR, Seamans JK, Gorelova N (1999). Developing a neuronal model for the pathophysiology of schizophrenia based on the nature of electrophysiological actions of dopamine in the prefrontal cortex. Neuropsychopharmacology 21: 161-194. 